\title{
Kosovo's Security Policy in Preventing and Fighting Trafficking of Human Beings 2009-2014
}

\author{
PhD. Cand. Reshat Maliqi \\ Police, Prishtinë - Kosovë \\ reshatmaliqi60@gmail.com
}

\begin{abstract}
Development of policies for the prevention of every nature of organized crime from the security institutions of the Republic of Kosovo is an important element through which is aimed the coordination of works and prevention activities in order to respond to negative phenomena through taking precautions. Prevention means all activities that impact on halting and reducing crime as a social phenomenon, both quantitatively as well as qualitatively, through occasional initiatives (ad hoc). Advancing capacity to prevent crime is the need of the time and the challenge faced by the countries of the Western Balkans, especially Kosovo, because in this area there is still the old belief that only the police should be involved to prevent and fight trafficking of human beings. Nature and trends of trafficking of human beings have taken a direction in which the police as law enforcement agency cannot as such prevent these crime phenomena. Therefore, it is time imperative that in the field of crime prevention of human trafficking engage all relevant institutions with special emphasis on civil society and community in particular. To cope with the challenges of preventing and fighting trafficking of human beings, activities within state's territory are not sufficient, but it is vital that states align and coordinate activities at the regional level in real time, place and space identified for common actions. This paper aims to address this phenomenon not only in the case of Kosovo, but also in the Western Balkan region. The main thesis of this paper is the articulation of the problem in order to successfully prevent the phenomenon of trafficking of human beings through awareness of citizens, while from institutions is required opening of perspectives for new generations, for work and life, through economic development, fighting poverty, stimulating employment and preventing the migration in different countries. To successfully prevent crime, particularly trafficking in human beings, it is necessary that responsible institutions have sufficient human resources, specialized and equipped with technical tools and necessary technology, to have continuous specialized training and to deal with all phenomena of organized crime.
\end{abstract}

Keywords: prevention, fighting, crime, trafficking, capacity, training, technology, etc.

\section{INTRODUCTION}

Trafficking of human beings in Kosovo is a complex phenomenon and constantly shows changes in the form and manner of the performance. General nature of the crime of this act is hidden and victims are threatened, blackmailed, intimidated, deceived and systematically exploited by traffickers, therefore victims do not self-declare nor dare to speak about the situation in which they stand even if they talk to law enforcement personnel.

Current trends of human trafficking in Kosovo show that this criminal phenomenon is focusing more on internal trafficking (within Kosovo) and as a result the number of identified victims of trafficking is increasing, also in recent years there are more victims identified in locations/apartment/private homes than in night bars, which was not the case a few years ago.

The main form of trafficking, respectively the manner of victims exploitation still remain exploitation for the purpose of providing sexual services (forced prostitution) but also with some minor cases of forced begging.

Today, in the world, human trafficking in considered as modern slavery and, while one of the main goals of any democratic country which aims rule of law it is to combat human trafficking, as one of the most complex crimes, therefore through this research I tend to spread my knowledge associated with this offense that is prescribed by the Criminal Code of Kosovo, in particular highlighting the similarities and differences of the offense of trafficking with other similar criminal offenses, which essentially differ from human trafficking, as well as the position of human trafficking victim. By analyzing the causes and factors of human trafficking in our country, the applicable legislation in Kosovo, especially international cooperation, through 
this paper will attempt to somehow present some essential elements of this negative occurrence with elements of criminal act punishable with our legislation as well as international legislation. It is a known fact that international factors have paid special attention to combating this phenomenon with the release of a series of measures and adequate laws, because this complex crime more and more has been growing in its entirety as a phenomenon, more complex methods are added to this crime and also have highlighted the weakness of the state towards the crimes of this kind. International and multilateral cooperation can play an important role in combating trafficking activities.

\section{The definition of trafficking offenses under the laws of Kosovo}

For its nature and its content, this offense is very close to the crime of smuggling people, because even with this offense human beings are treated as objects, where human dignity, the basic rights and freedoms are violated. Moreover, as Professor Kambovski asserts, human being is degraded and treated like an animal! (Kambovski V.,2011:1203). The name itself "human trafficking" quite clearly shows that this offense trades and alienates people, where the main goal is the realization of material benefits. Under paragraph 1 Types of actions which are conducted by this criminal act are determined alternatively and as such are numerous and complex. Consequently, as a form of commission of this offense is considered; recruitment, transfer, harboring or admission of trafficked persons (victims) with the aim of exploitation in different ways such as; sexual exploitation or other forms of sexual exploitation, forced labor or services, slavery or practices similar to slavery, servitude or removal of organs (illegal transplant of organ).

In paragraph 2, as a serious form of human trafficking offense is considered the case if the offense in paragraph 1 of this Article is committed in a circumference of 350 meters of a school or other locality which is used for children, or when the offense is committed against a person under eighteen years old. In paragraph 3 is foreseen a special form of this offense which is considered as such by the fact that someone has organized a group, or when there is a established group of persons for the purpose of committing the offense of human trafficking foreseen in paragraph 1 of this article (Salihu I.,2014:138). In paragraph 4 it is also foreseen severe form of human trafficking if the foreseen offense in three previous paragraphs is committed by an official by misusing official position. While in paragraph 5 as a severe form of human trafficking is considered human trafficking offense which caused the death of one or many persons.

The example of very severe form of human trafficking where death of people was caused was trafficking citizens from Albania to Italy across the Adriatic Sea by raft on January 9, 2004, which killed 28 people. Also very serious case of this offense was trafficking of Kosovars, where in October 2009, in the border between Serbia and Hungary, in the Tisa River drowned 17 people, among them women and children. All these forms of crime of human trafficking may be committed by any person, except this form of the offense foreseen in paragraph 7 of this article, which can be committed only by official person. This offense is considered to have been committed even when the passive subject (trafficked person) has given consent to be trafficked (paragraph 6, point 3). Regarding the guilt, all forms of this offense, can be committed intentionally. Sentences for the offense from paragraph 1 punishable by a fine and imprisonment up to twelve years, sentences for offenses from paragraph 2, a fine and imprisonment of up to fifteen years, sentences for offenses from paragraph 3 , a fine of up to 500,000 euro and by imprisonment of seven to twenty years, for the first offense from paragraph 4 are foreseen different sentences, while for the offense from the paragraph 5 , imprisonment of at least ten years or life imprisonment (Idem; Pg. 138).

\section{Regional and international instruments which relate directly to trafficking and forced labor}

Human trafficking is foreseen as a criminal offense with a relatively large number of international conventions. The most important international conventions prohibiting and punishing human trafficking are; Convention on the prohibition of the white slave trade 1910; Convention for the punishment of trafficking of women and children, 1921; Convention for the punishment of adult women trafficking of 1933 and the Convention on the punishment and prevention of human trafficking and their exploitation for prostitution of 1949 and the Convention on the prevention of human trafficking and exploitation of others 1950.

\section{General knowledge and statistics on human trafficking in Kosovo}

According to reports from international organizations, about 2 to 4 million people are trafficked worldwide each year, approximated by the United Nations. According to the National Crime Squad in the UK around 200,000 people are brought illegally to Europe every year, most of whom come for sexual exploitation. About 200,000 people are trafficked in Europe 
every year; the majority is women and girls forced into prostitution. While, according to the State Department of USA, $80 \%$ of victims are trafficked into the international borders are female and $70 \%$ of them (women) are trafficked for sexual exploitation. An estimated 7-13 billion dollars profit is generated annually from trafficking. While, based on official statistics on the number of cases that are prosecuted in the courts of Kosovo during period 2009-2104, we find that there is not such a large number of them, compared with reports of various organizations, stating that there is a large number of cases of human trafficking, but which were not detected and investigated by the investigating authorities. Below, for comparative needs, I will present tables in which are presented the numbers of cases received in the district courts, from 2009 to 2014 (Police Reports: 2009-2014).

Table 1 Victims identified by age group - 2009

\begin{tabular}{|l|l|l|l|l|l|l|l|l|}
\hline & & & & & & & & \\
Age & $14--17$ & $18--22$ & $23--25$ & $26--30$ & $31--35$ & $36--40$ & $41-50$ & Totali \\
\hline Female & 7 & 7 & 6 & 2 & 3 & 3 & 1 & 29 \\
\hline
\end{tabular}

Table No. 2 Cases/offenses from 2009 to 2014

\begin{tabular}{|l|l|l|l|l|l|l|}
\hline & 2009 & 2010 & 2011 & 2012 & 2013 & 2014 \\
Cases by criminal acts & & & & & & \\
\hline Human trafficking & 32 & 31 & 28 & 32 & 38 & 28 \\
\hline Provision of prostitution & 4 & 8 & 11 & 26 & 18 & 24 \\
\hline Dealing with prostitution & 11 & 14 & 17 & 30 & 15 & 21 \\
\hline Other acts & 22 & 4 & 10 & 4 & 17 & 16 \\
\hline Total & 69 & 57 & 66 & 92 & 88 & 89 \\
\hline
\end{tabular}

Table 3. Arrests based on criminal offenses from 2009 to 2014

\begin{tabular}{|l|l|l|l|l|l|l|l|}
\hline & $\mathbf{2 0 0 9}$ & $\mathbf{2 0 1 0}$ & $\mathbf{2 0 1 1}$ & $\mathbf{2 0 1 2}$ & $\mathbf{2 0 1 3}$ & $\mathbf{2 0 1 4}$ & Totali \\
\hline Human trafficking & 34 & $\mathbf{7 6}$ & 91 & 121 & 91 & 66 & 479 \\
\hline Provision of prostitution & 3 & 13 & 39 & 39 & 35 & 35 & 164 \\
\hline Prostitution & 9 & 27 & 50 & 61 & 26 & 49 & 222 \\
\hline Placement of slavery & & & 1 & & 0 & & 1 \\
\hline Other acts & 6 & 5 & 2 & 7 & 30 & 11 & 61 \\
\hline Total number of arrest & $\mathbf{5 2}$ & $\mathbf{1 2 1}$ & $\mathbf{1 8 3}$ & $\mathbf{2 2 8}$ & $\mathbf{1 8 2}$ & $\mathbf{1 6 1}$ & $\mathbf{9 2 7}$ \\
\hline
\end{tabular}

Table No.4 trafficking victims identified by nationality in Kosovo 2009-2014

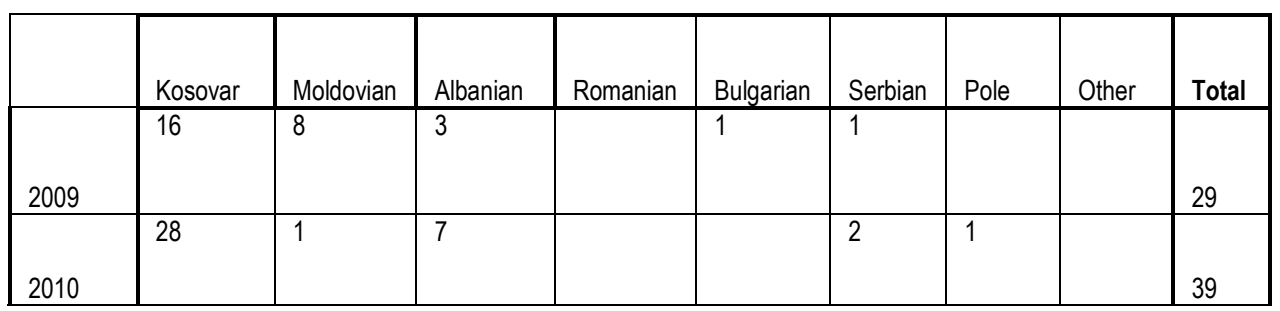




\begin{tabular}{|c|c|c|c|c|c|c|c|c|c|}
\hline 2011 & 35 & & 1 & & & 3 & & & 39 \\
\hline 2012 & 29 & 23 & 1 & & & & & 1 & 54 \\
\hline 2013 & 44 & & 7 & & & 1 & & & 52 \\
\hline 2014 & 36 & & 4 & 1 & & 1 & & & 42 \\
\hline Total & 188 & 32 & 23 & 1 & 1 & 8 & 1 & 1 & 255 \\
\hline
\end{tabular}

Table No. 5 victims of trafficking identified by level of education in Kosova 2009-2014

\begin{tabular}{|c|c|}
\hline Victims - level of education 2009-2014 & $\mathrm{Nr}$ \\
\hline Illiterate & 23 \\
\hline Initial education & 158 \\
\hline Secondary education & 70 \\
\hline University & 4 \\
\hline Total & 255 \\
\hline
\end{tabular}

No. 6 victims of trafficking identified by means of recruitment in Kosovo 2009-2014

\begin{tabular}{|l|l|}
\hline Victims - manners of recruitment 2009-2014 & $\mathrm{Nr}$ \\
\hline Job offers/promises & 141 \\
\hline Promise for marriage & 75 \\
\hline Tourism & 1 \\
\hline Other & 39 \\
\hline Total & 255 \\
\hline
\end{tabular}

Table No. 7 Victims of trafficking identified in the manner of exploitation in Kosovo from 2009 to 2014

\begin{tabular}{|l|l|}
\hline The form of exploitation of victims 2009-2014 & $\mathrm{Nr}$ \\
\hline Sexual exploitation/forced prostitution & 190 \\
\hline Forced labor & 31 \\
\hline Forced begging & 16 \\
\hline Holding in slavery and servitude & 18 \\
\hline Exploitation for organ removal & 1 \\
\hline Total & 255 \\
\hline
\end{tabular}




\section{Factors favoring human trafficking in Kosovo}

The Kosovo war 1997-1999, is manifested in the economic and social consequences which largely affected people. Over 120 thousand homes were destroyed, family and economic situation in Kosovo especially that of the village came under the average level down to extreme poverty, demographic movement occurred, the population largely migrated from the villages to the cities. The unemployment reached high up to $70 \%$. Many families had killed members in the war and were left without any source of existence. Many children from poverty had to leave school and look for work to support themselves and their families, all of which were prerequisites that networks of traffickers from different countries of the world, come to Kosovo to recruit local traffickers, but also for Kosovar trafficked victims.

Criminal activity of traffickers of human beings becomes even easier by the absence of its preventive mechanisms, such as the security institutions of the country and state institutions. Initially, immediately after the war of 1999 human trafficking began with victims from post-communist countries of Eastern Europe, but soon the local Kosovar victims too. As statistics show, the trend of trafficking of Kosovo victims has increased from year to year, but this figure is only of those who were identified and rescued from trafficking, because the number of trafficking victims is many times larger and under Kosovo Police reports, it can be around 2 thousand victims from 1999 onwards.

The legal basis for preventing and combating human beings trafficking in Kosovo is based on these laws, regulations and national documents as follows:

- The law on preventing and combating human trafficking and protecting victims

- Law on Foreigners

- The law on compensation of victims of crime

- National Strategy on Combating Trafficking of Human Beings and action plan 2015 to 2019.

- Standard operating procedures for trafficked persons in Kosovo

- Minimum standards for the care of victims of trafficking

- Long-term strategy for the reintegration of victims

To these general factors favoring human trafficking are also added individual factors of trafficked victims, as is the age of the victims, mainly between the ages of 14 and 18, which is the age of lability, education of victims (many victims are illiterate, with primary and secondary education), poor economic condition of the family of the victims, as well as the stability of their families (families with divorced parents or with presence of domestic violence). Increased number of victims assisted and rescued, presents the result of the work of institutions to combat human trafficking in our country. However, the largest number of local victims is trafficked to Western Europe, who are never rescued and continue to live as victims of human trafficking. The first cases of human trafficking in Kosovo are marked with victims of the Southeast European countries ${ }^{1}$ which come from countries where unemployment is high and where traffickers deceive the victims with the promise of employment, but exploit them exclusively for practicing commercial sex. Foreign victims of trafficking are brought to Kosovo after the war, in order to provide employment in prostitution, whom would be used by international workers. Kosovo's new residents, who come from all over the world, have been and continue to be regular clients of sex workers. Immediately after the war, Kosovo was considered as a high risk country, so the international community would not allow its employees to bring their families with them, or many of them were unmarried. International workers were also advised not to enter in relationship with local women, because according to the traditions of the local population, it can be dangerous.

\section{Protection and assistance for victims}

Protection of victims of trafficking remains a challenge for the institutions of Republic of Kosovo despite the fact that progress has been made in creating adequate conditions for protection measures, housing and reintegration of trafficking victims. The cooperation and contribution of civil society organizations is of particular importance, especially those that provide specialized services and expertise in dealing with this sensitive issue. Government of Kosovo supports the issues 
of protection and reintegration of victims of trafficking and in 2012 provided support to 43 victims of trafficking, while in 2013 provided support to 52 victims of trafficking'.

A particular progress concerning the protection of victims of trafficking is the review of standard operating procedures to reflect changes made in the new criminal code, in particular for police officers and social workers about the referral of trafficking victims after their identification. The Ministry of Justice is drafting Law on Compensation of Victims of Crime by whom the program for compensation of victims of crime will be functional and will be in accordance with Council Directive 2004/80/EC of April 29, 2004, concerning the compensation of victims of crime.

\section{The creation of safe conditions for repatriation and resocialization of victims}

Proper protection and support should be extended to all trafficked persons without discrimination. However, victims are being saved from traffickers often face difficulties to reintegrate in society. In order to overcome this problem, legal and other material assistance should be provided to trafficked persons to enable them to realize their right to adequate and appropriate improvements. The needs of victims of trafficking can be different:

1) Basic needs and requests for accommodation, food, medical control, communication with family, etc. (Netkova, B;2009:152)

2) Health needs - headaches, anxiety, stress, anxiety, various diseases.

3) Legal needs - legal representation, counseling, representation from victim protection unit, etc.

Protecting witnesses from threats or intimidation has been and remains one of the greatest challenges for the judicial system in Kosovo. This issue has been repeatedly raised in the reports of various international organizations on justice. Incidents of witness intimidation continue to hamper the proper functioning of the justice system, especially in high profile criminal cases.

\section{International cooperation with countries and international organizations in combating the phenomenon of trafficking}

Trafficking is a regional and global phenomenon that cannot always be dealt with effectively at the national level, so strengthened national response can often result in the operations of traffickers elsewhere. International and multilateral cooperation can play an important role in combating trafficking activities. States should adopt appropriate legislation and other necessary measures to prevent and combat trafficking and its acts as: the adaptation of bilateral agreements aimed at preventing trafficking, protecting the rights and dignity of trafficked persons and support their welfare; provision, on bilateral basis or through multilateral organizations, technical and financial assistance, countries and relevant sectors of civil society in order to aid the development and implementation of anti-trafficking strategies based of human rights; implementation of regional and sub-regional treaties on trafficking, using the Palermo Protocol and relevant international standards of human rights as a starting point and framework; adoption of labor migration agreements, which may include provision for minimum work standards, model contracts, modes of repatriation, etc., in accordance with existing international standards.

\section{Conclusions}

One can conclude that the 1999 war in Kosovo is associated with direct impact on the welfare of the population. Over 120 thousand homes were destroyed, family and economic situation in Kosovo especially that of the village came under the average level down to extreme poverty, and demographic movement occurred, the population largely migrated from the villages to the cities. The unemployment reached high up to $70 \%$. Many families had killed members in the war and were left without any source of existence. Many children from poverty had to leave school and look for work to support themselves and their families. Most of the victims are rural origin, have lived their childhood in a poor economic situation, have been

\footnotetext{
${ }^{1}$ http://ec.europa.eu/enlargement/pdf/key_documents/2013/package/ks_rapport_2013.pdf 
unable to attend school, or lived in families with divorced parents and did not see any perspective for their lives, and therefore are easily misled by traffickers. The survivors of trafficking are not well received by the social and family circle, state institutions do not offer anything for re-integration into society, and they do not offer accommodation, food or employment for them to live independently. They live in safe houses which IOM offers, but their life is isolated, as if they were prisoners, with controlled freedom of movement. The victims have dilemmas about their lives. Clients of trafficking victims (which are used for prostitution), are mainly people who are rich, are married and have children, but visiting commercial sex workers, because according to them, they are beautiful and attractive.

Therefore trafficking has affected Kosovo families by stimulating and causing adultery. These clients of sex workers think that "prostitutes" are immoral along with their clients, excluding themselves, but in reality they are within this circle. Today, however small, only 95, the number of internal trafficking victims, represents a layer of contemporary Kosovar society, which must face our society and institutions, to integrate and to enable a normal life, as already has been saved. However, this number has a increasing trend and institutions of the country and our society must face, prevent and combat this phenomenon, in order not to mark an enormous increase which would become unbearable for our society. This phenomenon, if not fought now by local institutions, risks spreading even more and affecting the whole structure of Kosovar society.

\section{Recommendations}

At the core of this continuous and uncompromising struggle should be:

- Measures for judiciary reform. They must be accompanied by completing the legal framework according to international standards and specific conditions of our country.

- $\quad$ Full identification and strict punishment of the human trafficking organizers and their helpers.

- Specialized assistance to victims and their rehabilitation, starting with medical and psychological treatment and then create the conditions for employment at home and abroad.

- Increase of awareness to the public, particularly information of minors and young people about this ugly and inhuman phenomenon.

- $\quad$ Reduction of poverty and political tensions with social and other harmful consequences.

\section{Literature:}

[1] Netkova. B. analysis of human trafficking in organized crime aspects, Tetovo, 2009

[2] Kambovski, V., Commentary of criminal law of Republic of Macedonia, Skopje, 2011.

[3] I. Salih, Criminal law - special part, Pristina, 2014

[4] Police Reports 2009-2014.

\section{Sources from the Internet:}

[1] Int'l Organization for Migration Data on Human Trafficking in Kosovo

[2] 2013 Progress Report on Kosovo, 2013 